\title{
Online Baseline Assessment in Mathematics: Initial Teacher Education Entry-Level Student Performance
}

\author{
Folake Modupe Adelabu \\ Jogymol Alex \\ Walter Sisulu University, \\ Nelson Mandela Drive, \\ Mthatha, South Africa
}

DOI: https://doi.org/10.36941/ajis-2022-ooo6

\begin{abstract}
This article describes a part of an online and technological intervention at a rural South African Higher Education Institution focused at improving the mathematical knowledge of first-year Senior Phase and Further Education Training (SPE FET) Bachelor of Education student teachers. As part of the interventions in an ICT integrated Mathematics Education and Research Centre, the student teachers were subjected to write an online baseline assessment on the content knowledge in Grade 7 mathematics, which is the first year in Senior Phase in South African Schools. A total of 193 student teachers wrote the online baseline test with 20 items in an invigilated computer laboratory environment. The test items were from the online Computer Aided Mathematics Instruction (CAMI) program which is aligned to the Grade 7 CAPS curriculum of South Africa. The data were analysed by the CAMI system and were further analysed using Microsoft Excel 2016. The result of the test showed an average performance of $38,67 \%$ (Variance: o, 66\% and SD: o, $81 \%$ ). This sheds light into the disturbingly limited mathematics subject content knowledge the student teachers enter the HEI with. The programme structure of the Senior Phase mathematics content module of the HEI was also analysed. The authors of this paper recommend that student teachers need to be thoroughly engaged in learning the content during their training as future mathematics teachers. This paper contributes to the ongoing research on ITE programmes at HEIs that prepare teachers for their mathematics teaching role in the senior Phase classrooms.
\end{abstract}

Keywords: Online assessment; Initial teacher education (ITE); mathematical knowledge for teaching; online baseline assessment; entry-level student performance

\section{Introduction}

Teachers and their initial training for teaching are blamed for the critical challenges in mathematics teaching and learning in the South African education system. Many studies (for example, Legotlo, Maaga, and Sebego 2006; Kriek and Grayson 2009; Bansilal, Brijlall, and Mkhwanazi 2014; Alex 2019) have found that teachers do not have a thorough understanding of the mathematics that their learners must acquire. The performance of mathematics learners in the matric examination is on a decline and the South African subsample of the international benchmarking TIMSS 2019 study is still showing wide gap in the performance (with 389 points, whereas 500 is the centre point as reported by 
Department of Basic Education (2020)). Many researchers believe that one of the reasons for this low performance is teachers' lack of mathematical expertise, and that strengthening teachers' mathematical knowledge will enhance learner achievement (see Pournara, Hodgen, Adler, and Pillay, 2015; Alex \& Roberts 2019; Alex 2021). This demands a major overhaul of initial teacher education (ITE) curricula in mathematics. This paper, written in the context of interventions aimed at improving mathematical knowledge for teachers, is based on the premise that reinforcing the curriculum content of the teachers' initial teacher education programme, as well as student teachers' own knowledge of the content that they must teach, will improve student teachers' ability to teach their future learners. This will solve learners' poor performance in South African classrooms.

As a result, the following research questions are addressed in this paper:

1. What evidence can be made from the current curriculum opportunities for student teachers to address the mathematical skills required to teach in Grade 7 (Senior Phase)?

2. What evidence can be drawn from the performance of entry level student teachers in the online test on the mathematical knowledge needed to teach in Grade 7 ?

To answer the research questions, the curriculum documents of the course content of the Senior Phase ITE programme and entry level student teachers' performance in an online test in Grade 7 topics were analysed. Even though the student teachers wrote baseline tests in all grades in the Senior Phase curriculum, only the performance in Grade 7 test is reported in this paper.

\section{Literature}

\subsection{The initial teacher education landscape}

Any mathematics teacher education program's principal goal is to prepare (student) teachers to teach classroom mathematics. One of the most difficulties facing mathematicians who want to improve student learning is preparing teachers to successfully teach mathematics (Morris, Hiebert \& Spitzer, 2009). Challenges in mathematics teacher preparation are not a new source of concern on a global scale. The National Research Council (NRC, 1996) cited studies from the 1970s and 1980s (e.g., Lortie, 1975; Loucks-Horsley et al., 1987) and stated that "teacher preparation-the formal trainings of prospective teachers-is only one part of a continuum of experiences that contribute to the process of learning to teach," as they are influenced by their own background. A prospective teacher's undergraduate preparation serves as a bridge between their pre-college experiences and their first year of teaching, as well as a basis for future professional development. In many countries, however, building teachers' MKfT remains a difficulty, as pre-service teacher education programs sometimes give very little possibilities for this development (Martinez, Guez, Zamora, Bustos, \& Rodrguez, 2020). It is important to know what we can do to support pre-service teachers' professional development right from the outset of their education (Rocha, 2020). Learning to become a competent and proficient teacher is a complicated process that entails more than simply subject-matter knowledge (Zinn, Geduld, Delportn \& Jordaan, 2014). For decades, researchers have debated what type of knowledge a teacher should have (Shulman, 1986; Ball et al., 2008), and more specifically, "What Mathematics" should a teacher know (Ma, 1999). Many specialists and researchers in the field have developed theories that have become the foundation of many teachers' education programs around the world. Latterell (2008) proposes that mathematics teachers need content knowledge, pedagogical knowledge, and pedagogical-content knowledge, based on the premise that teachers teach as they have been taught' (Brown \& Borko, 1992). We need to look at how preservice teachers can increase their knowledge of the mathematics content they want to teach, the experiences that are helpful in developing effective teaching strategies and continue research on frameworks that help them in effective subject matter preparation. According to Leitzel (1991), the substance of university courses must contain changes in emphases and content of the emerging school curriculum, as well as the ever-changing scope of mathematics itself, as stated by NRC (1996).

In response to NRC's (1996) question and the ongoing debate over whether student teachers 
require to know specific mathematics in specific ways that will have the greatest impact on their subsequent classroom practice, the authors of this paper believe that ITE courses must give opportunities for student teachers to learn the mathematics content at least at the same level as their future students in a particular grade level. The National Research Council (1996, p.12) in its report "the preparation of teachers of mathematics: considerations and challenges." concluded that subject content matters. Mathematicians and mathematics educators face a significant issue in deciding what subject content to cover, for whom, and in what depth. The authors of this paper also feel that what NRC (1996) mentions is relevant to any teacher preparation courses in mathematics. Even after decades of the above report, the studies conducted in South Africa on initial teacher education (ITE) programs still show that enough content at the level of the school teaching is still not where it should be (for example, Initial Teacher Education Research Project (ITERP) in 2014; the ongoing Primary Teacher Education Project (PrimTEd), which started in 2016). Against this backdrop, this paper looks at the newly introduced Senior Phase mathematics education curriculum in a rural HEI. This curriculum was in response to the debate on the above issue in the South African context.

This study is twofold. Firstly, what is the mathematical content knowledge that the student teachers enter the programme with and secondly, what are the available opportunities for them to receive the perceived mathematical content knowledge in their Senior Phase ITE program in the selected rural HEI.

The context of the paper's origin is divided into the following two sections to provide evidence on the curriculum options available for student teachers to address the mathematical skills needed to teach in Grade 7 (Senior Phase).

\subsection{Grade 7 Curriculum CAPS document in the south African context}

As specified in the Curriculum and Assessment Policy Statements (CAPS, DBE, 2011), Mathematics in the Senior Phase covers five main Content Areas:

- Numbers, Operations and Relationships

- Patterns, Functions and Algebra

- Space and Shape (Geometry)

- Measurement; and

- Data Handling

The development of distinct talents is aided by each topic area. Learners are expected to learn essential mathematical skills such as correct use of the mathematical language, number vocabulary, number concept, calculation, and application skills; learn to listen, communicate, think, reason logically, and apply the mathematical knowledge gained; learn to investigate, analyze, represent, and interpret information, and learn to pose questions (CAPS, DBE, 2011). These considerations were in the forefront in the preparation of the curriculum for the selected rural HEI's Senior Phase ITE.

\subsection{Senior Phase mathematics content in the initial teacher education programme in the selected rural HEI}

In South Africa, the majority of initial teacher education (ITE) programs are four-year degree programs conducted by HEIs. In the ITE programme of the selected rural HEI, where this research is conducted, student teachers are exposed to two years of mathematics content that they are expected to teach in the Senior Phase. The purpose of the module as specified in the Programme Structure (selected HEI, 2021) for Senior Phase mathematics content is to equip student-teachers with adequate mathematical knowledge to be effective in teaching Senior Phase mathematics; acquire the necessary analytic and technical skills to handle problems and to provide the foundation for further specialisation in this field. Numbers, Operations, and Relationships; Patterns, Functions, and Algebra; Space and Shape (Geometry); Measurement and Data-Handling; and Probability are among 
the topics covered in this module. The program is designed to assist student teachers in developing a grasp and accurate use of mathematical language, number vocabulary, and number concepts. Students will be expected to learn how to explain key terminology, concepts, facts, general principles, and rules of mathematics that are pertinent to Senior Phase instruction. By the completion of the course, they should be able to provide knowledge in the core content and learning outcomes of Mathematics. A detailed course module is attached in the analysis section of this paper.

\section{Mathematical Knowledge for Teaching}

One strategy to improve student teachers' preparedness to teach the discipline is to identify the particular mathematical knowledge that boosts their success (Martinez, et al., 2020). Many studies have been conducted on Ball, Thames, and Phleps (2008)'s Mathematical Knowledge for Teaching (MKfT), which is based on Shulman's seminal work (1986). With its several realms of knowledge, the MKfT framework has been widely utilised as a framework for preparing mathematics student teachers to teach mathematics in schools.

Ball, Thames, and Phelps (2008) defined mathematical knowledge for teaching (MKfT) as the "mathematical knowledge needed to carry out the activity of teaching mathematics" (Ball, Thames, and Phelps, 2008), which was based on Pedagogical Content Knowledge (PCK) proposed by Shulman's (1986). Our paper is based on Ball and her team's (Ball, Thames, \& Phelps, 2008) eminent work since 2008 and the domains as espoused by them, particularly on their mathematical knowledge for teaching model of 2008 , with a focus on student teachers' specialized content knowledge (SCK) and Knowledge of content and curriculum (KCC). Through the baseline test, the student teachers were introduced to SCK, the topic, and the curriculum they would be teaching.

Specialized Content Knowledge (SCK) is defined as a knowledge teachers obtain when employed with certain responsibility to teach which is not useful in any profession rather than teaching (Ball, Thames \& Phelps (2008); Jacinto \& Jakobsen (2020); Sahidin, Budiarto \& Fuad (2019)). For instance, the SCK is the responsibility that teachers perform in the classroom that require a specific mathematical knowledge with special skills when introducing mathematics instruction and answer students' questions. The SCK is part of the material content knowledge domain of mathematical knowledge. Therefore, the acquired knowledge by student teachers from being exposed to CAMI is a special knowledge of mathematics which supports the taught curriculum in the HEI.

Teachers gain knowledge of content and curriculum (KCC) in order to grasp both mathematical content and curriculum. The knowledge is obtained when using teaching materials and at different grade levels. The KCC is part of the pedagogic content knowledge domain of mathematical knowledge (Ball, Thames \& Phelps, (2008); Sahidin, Budiarto \& Fuad, (2019)). It is anticipated that by exposing the students to a baseline test will motivate them to attain the SCK and CCK relevant to the Senior Phase teaching. It is also anticipated that this would make informed decisions on interventions to address the deficiencies in their SCK and CCK.

\subsection{The CAMI baseline test}

One of the keys aim of mathematics assessment, according to Nortvedt and Buchholtz (2018), is to give evidence that may be utilised to make judgments about or improve mathematics education. Having the view on assessment, the authors of this paper used CAMI test to assess the student teachers' SCK and CCK. CAMI test is an online baseline test available in the CAMI EduSuite program (further information is available from www.cami.co.za). The Grade 7 baseline test consisted of a 6ominute online test with 20 items. Each item was worth a single point. These products were created using South Africa's Grade 7 Mathematics CAPS curriculum. Numbers, Operations, and Relationships, Patterns, Functions, and Algebra, Space and Shape (Geometry), Measurement, and Data Handling were among the topics covered. The test covered both high and low order cognitive level items. The tools' face validity and trustworthiness were demonstrated. 
Below are some of the sample items from the CAMI test.

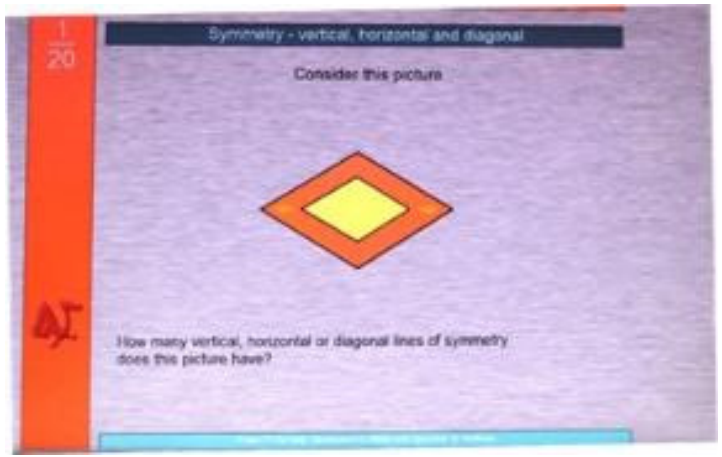

Figure 1: Test Item no: 1

Source: www.cami.co.za

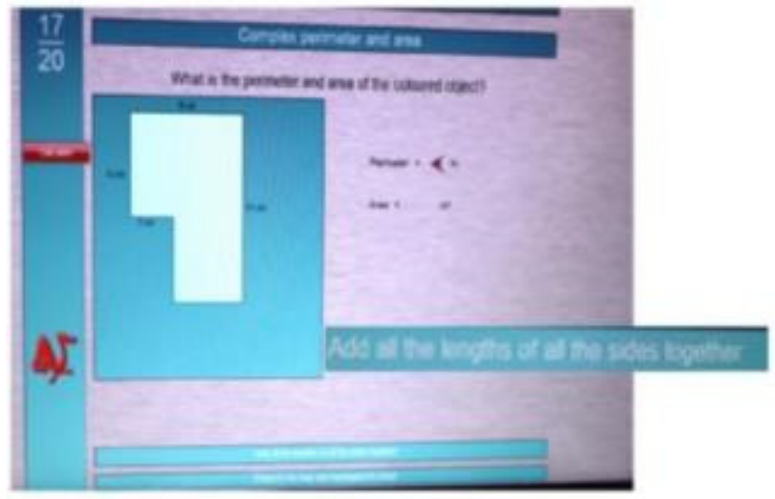

Figure 2: Test Item no: 17

Source: www.cami.co.za

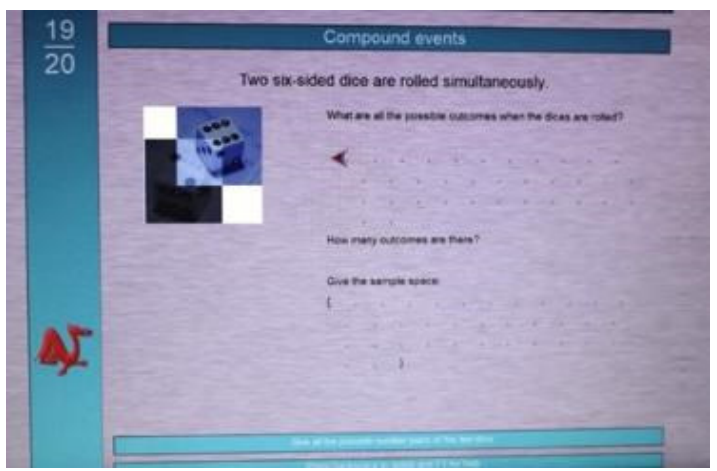

Figure 3: Test Item no: 19

Source: www.cami.co.za 


\section{Methodology}

The CAMI baseline tests were part of the intervention organised by the research team at the Mathematics Education and Research Centre at a HEI in the Eastern Cape Province, South Africa. The Centre mainly aims at developing the competencies in mathematics teaching of pre-service mathematics education students. For the first time in its history, the HEI implemented a Senior Phase and Further Education and Training (SP\&FET) Phase teaching program in 2021. The program was launched in accordance with the Department of Higher Education and Training (DHET) of South Africa's minimal criteria for tertiary education qualification framework (MRTEQ, 2015). Online exams with the licensed on-line CAMI program for all grades (Grades 7 -12) were intended to assess the topic material understanding of the entry level student instructors. With the consultation of the lecturer in charge of the first-year students, the student teachers were subjected to write the tests before the start of the new teaching program. Three lab assistant and two lecturers monitored the processes of the tests. A total of 193 student teachers wrote the online baseline test in an invigilated computer laboratory environment in May 2021 in 3 sessions to observe covid protocols. Each test was one hour long. The student teachers gave the consent to participate in the study and all the ethical requirements were met (Ethical Clearance Number: FEDSRECCoo1-o6-22).

The study used a quantitative research method using test data for first-year teacher education students' specialised content knowledge for teaching. The quantitative research method approach described the first-year teacher's learning through computer aided instruction.

\section{Results and Data Analysis}

The following mapping of the ITE program's mathematical material with Grade 7 mathematics subject was done to answer the first research question. This sought to show the possibilities for student teachers to address the mathematics skills required to teach in Grade 7. (Senior Phase).

Table 1: Mapping of the mathematics content knowledge: Senior Phase in the CAPS document and the ITE programme

\begin{tabular}{|c|c|c|c|c|}
\hline Content area & $\begin{array}{l}\text { Senior Phase specific content } \\
\text { focus as specified in the CAPS: } \\
\text { Senior Phase (source: CAPS, } \\
\text { DBE 2011) }\end{array}$ & \begin{tabular}{|l|} 
Senior Phase Learning \\
outcomes and \\
Associated \\
Assessment Criteria in \\
the Programme \\
structure: Senior \\
Phase in Year 1 \\
(source: Selected HEI, \\
2021) \\
\end{tabular} & $\begin{array}{l}\text { Senior Phase specific content } \\
\text { focus as specified in the } \\
\text { Programme structure: Senior } \\
\text { Phase in Year I (source: } \\
\text { Selected HEI, 2021) }\end{array}$ & $\begin{array}{l}\text { Senior Phase specific } \\
\text { content focus as } \\
\text { specified in the } \\
\text { Programme structure: } \\
\text { Senior Phase in Year } 2 \\
\text { (source: Selected HEI, } \\
\text { 2021) }\end{array}$ \\
\hline $\begin{array}{l}\text { Numbers, } \\
\text { Operations } \\
\text { and } \\
\text { Relationships }\end{array}$ & $\begin{array}{l}\text { Representation of numbers in } \\
\text { a variety of ways and moving } \\
\text { flexibly } \\
\text { between representations } \\
\text { - Recognising and using } \\
\text { properties of operations with } \\
\text { different number } \\
\text { systems } \\
\text { - Solving a variety of problems, } \\
\text { using an increased range of } \\
\text { numbers and the } \\
\text { ability to perform multiple } \\
\text { operations correctly and } \\
\text { fluently }\end{array}$ & $\begin{array}{l}\text { When solving } \\
\text { problems, the } \\
\text { students will be able } \\
\text { to recognise, describe, } \\
\text { represent, and work } \\
\text { confidently with } \\
\text { numbers and their } \\
\text { relationships to } \\
\text { estimate, calculate, } \\
\text { and check solutions; }\end{array}$ & $\begin{array}{l}\text { Whole numbers, multiples and } \\
\text { factors, Integers, Properties of } \\
\text { integers, Fractions, types of } \\
\text { fractions, common fractions, } \\
\text { decimal fractions, mixed } \\
\text { numbers, which includes } \\
\text { grouping, sharing, and finding } \\
\text { fractions of whole numbers; } \\
\text { ratio and rate, direct and } \\
\text { indirect proportion, Exponents, } \\
\text { perform calculations involving } \\
\text { all four operations using } \\
\text { numbers in exponential form, } \\
\text { using the laws of exponents. }\end{array}$ & $\begin{array}{l}\text { Solve problems in } \\
\text { contexts involving } \\
\text { numbers in } \\
\text { exponential form, } \\
\text { including scientific } \\
\text { notation, multiple } \\
\text { operations with } \\
\text { integers, percentages, } \\
\text { and decimal fractions } \\
\text { in financial contexts. }\end{array}$ \\
\hline $\begin{array}{l}\text { Patterns, } \\
\text { Functions } \\
\text { and Algebra }\end{array}$ & $\begin{array}{l}\text { Investigation of numerical and } \\
\text { geometric patterns to establish } \\
\text { the }\end{array}$ & $\begin{array}{l}\text { The students will be } \\
\text { able to investigate, } \\
\text { analyse, describe, and }\end{array}$ & $\begin{array}{l}\text { Numeric and geometric } \\
\text { patterns, Describe and justify } \\
\text { the general rules for observed }\end{array}$ & $\begin{array}{l}\text { Aalgebraic } \\
\text { expressions, simplify } \\
\text { algebraic expressions, }\end{array}$ \\
\hline
\end{tabular}




\begin{tabular}{|c|c|c|c|c|}
\hline & \begin{tabular}{|l|} 
relationships between \\
variables \\
- Expressing rules governing \\
patterns in algebraic language \\
or symbols \\
- Developing algebraic \\
manipulative skills that \\
recognize the equivalence \\
between different \\
representations of the same \\
relationship \\
- Analysis of situations in a \\
variety of contexts in order to \\
make sense of \\
them \\
- Representation and \\
description of situations in \\
algebraic language, \\
formulae, expressions, \\
equations, and graphs
\end{tabular} & $\begin{array}{l}\text { represent a wide } \\
\text { range of functions } \\
\text { and solve related } \\
\text { problems; }\end{array}$ & $\begin{array}{l}\text { relationships between numbers } \\
\text { in own words or in algebraic } \\
\text { language, input and output } \\
\text { values, equivalent forms. }\end{array}$ & $\begin{array}{l}\text { algebraic equations, } \\
\text { drawing linear graphs } \\
\text { from given equations, } \\
\text { determining } \\
\text { equations from given } \\
\text { linear graphs. }\end{array}$ \\
\hline $\begin{array}{l}\text { Space and } \\
\text { Shape } \\
\text { (Geometry) }\end{array}$ & \begin{tabular}{|l|} 
Drawing and constructing a \\
wide range of geometric \\
figures and solids \\
using appropriate geometric \\
instruments \\
- Developing an appreciation \\
for the use of constructions to \\
investigate the \\
properties of geometric figures \\
and solids \\
- Developing clear and more \\
precise descriptions and \\
classification \\
categories of geometric figures \\
and solids \\
- Solving a variety of geometric \\
problems drawing on known \\
properties of \\
geometric figures and solids
\end{tabular} & $\begin{array}{l}\text { The students will be } \\
\text { able to describe, } \\
\text { represent, analyse, } \\
\text { and explain properties } \\
\text { of shapes in } 2 \mathrm{D} \text { and } \\
\text { 3D space with } \\
\text { justification }\end{array}$ & $\begin{array}{l}\text { Geometry of 2dimensional } \\
\text { shapes, solve geometric } \\
\text { problems involving unknown } \\
\text { sides and angles in triangles } \\
\text { and quadrilaterals using known } \\
\text { properties of triangles and } \\
\text { quadrilaterals, as well as } \\
\text { properties of congruent and } \\
\text { similar triangles. Use the } \\
\text { Theorem of Pythagoras to solve } \\
\text { problems involving unknown } \\
\text { lengths in geometric figures } \\
\text { that contain right-angled } \\
\text { triangles. }\end{array}$ & $\begin{array}{l}\text { Geometry of } 3 \mathrm{D} \\
\text { objects, use nets to } \\
\text { create models of } \\
\text { geometric solids } \\
\text { including cubes, } \\
\text { prisms, pyramids, } \\
\text { cylinders, Geometry of } \\
\text { straight lines, solve } \\
\text { geometric problems } \\
\text { using the } \\
\text { relationships between } \\
\text { pairs of angles, } \\
\text { Transformation } \\
\text { geometry- reflection, } \\
\text { translation, } \\
\text { enlargement and } \\
\text { reduction, } \\
\text { Construction of } \\
\text { geometric figures, }\end{array}$ \\
\hline Measurement & $\begin{array}{l}\text { Using formulae for measuring } \\
\text { area, perimeter, surface area } \\
\text { and volume of } \\
\text { geometric figures and solids } \\
\text { - Selecting and converting } \\
\text { between appropriate units of } \\
\text { measurement } \\
\text { - Using the Theorem of } \\
\text { Pythagoras to solve problems } \\
\text { involving right-angled } \\
\text { triangles }\end{array}$ & & & $\begin{array}{l}\text { Area and perimeter of } \\
2 \mathrm{D} \text { shapes, Surface } \\
\text { area and volume of } 3 \mathrm{D} \\
\text { objects- cubes, } \\
\text { rectangular prisms, } \\
\text { triangular prisms, and } \\
\text { cylinders. }\end{array}$ \\
\hline \begin{tabular}{|l|} 
Data \\
Handling
\end{tabular} & $\begin{array}{l}\text { Posing of questions for } \\
\text { investigation } \\
\text { • Collecting, summarizing, } \\
\text { representing and critically } \\
\text { analysing data in order } \\
\text { to interpret, report and make } \\
\text { predictions about situations } \\
\text { - Probability of outcomes } \\
\text { include both single and } \\
\text { compound events and their } \\
\text { relative frequency in simple } \\
\text { experiments }\end{array}$ & $\begin{array}{l}\text { The students will be } \\
\text { able to collect, } \\
\text { organise, analyse, and } \\
\text { interpret data to } \\
\text { establish statistical } \\
\text { and probability } \\
\text { models. }\end{array}$ & $\begin{array}{l}\text { Collect, organize, and } \\
\text { summarise data, draw a variety } \\
\text { of graphs by hand/technology } \\
\text { to display and interpret data } \\
\text { including bar graphs and } \\
\text { double bar graphs, histograms } \\
\text { with given and own intervals, } \\
\text { pie charts, broken-line graphs, } \\
\text { scatter plots. Probability: } \\
\text { Outcomes, Events. }\end{array}$ & $\begin{array}{l}\text { Interpret, analyse, and } \\
\text { report data; } \\
\text { Probability: relative } \\
\text { probability }\end{array}$ \\
\hline
\end{tabular}


Furthermore, according to the program structure, the competencies addressed by the module in the first two years of study state that Senior Phase Mathematics student teachers should have strong subject knowledge in the mathematical concepts of Numbers, Operations, and Relationships, Patterns, Functions, and Algebra, Space and Shape (Geometry), Measurement, and Data - Handling, as well as be knowledgeable about the mathematical concepts of Measurement and Data - Handling (Selected HEI, 2021).

It is anticipated that the student teachers would be exposed to all the content knowledge they need to learn for teaching effectively to their future learners.

\subsection{Entry level student teachers' performance in the Grade 7 baseline test}

The performance of student teachers in the Grade 7 test is depicted in the following graph (Figure 4).

The performance of the student instructors was presented using a Pareto chart. The results are presented in decreasing order, with a cumulative line as a percentage of the total on a secondary axis.

Microsoft Excel 2016 was used for this secondary analysis.

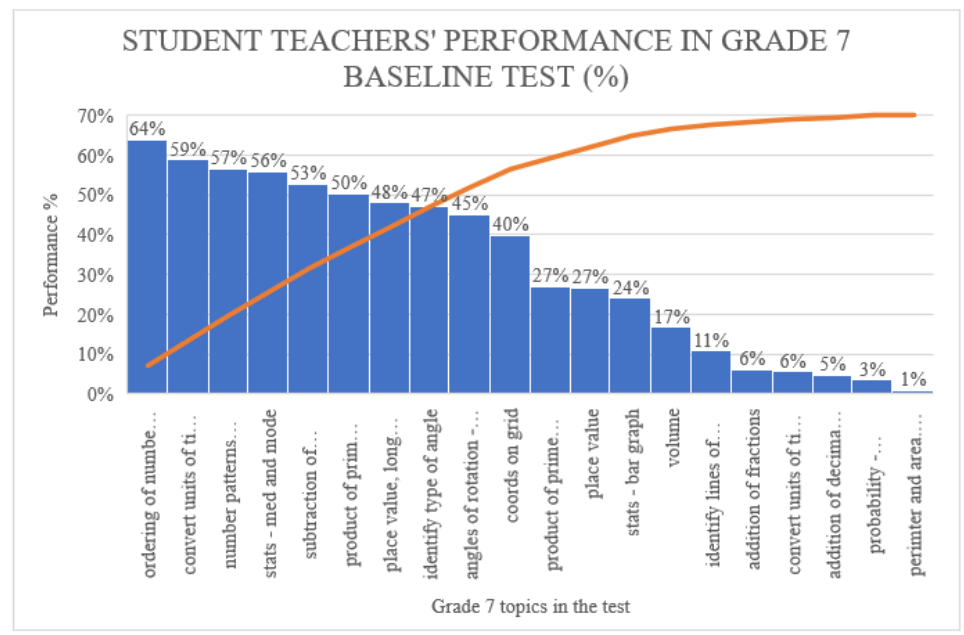

Figure 4: Entry level student teachers' performance in the Grade 7 baseline test

As shown in Figure 4, the highest three percentages of correct answers were for ordering of numbers $(64 \%)$, converting units of time $(59 \%)$ and number patterns $(57 \%)$. The lowest percentages were addition of decimals (5\%), Probability (3\%) and Perimeter and Area (1\%).

Table 2: Grade 7 Assessment analysis from CAMI reports

\begin{tabular}{|l|c|}
\hline Assessment name & Baseline Assessment_Grade o7 \\
\hline Assessment information & Baseline Assessment_Grade o7 \\
\hline English CAMI Literacy & 20 \\
\hline Number of questions & 193 \\
\hline Number of students used in analysis & 38.67 \\
\hline Assessment statistics & 0.66 \\
\hline Average percentage & 0.81 \\
\hline Distribution variance (\%) & 0.12 \\
\hline Standard deviation (\%) & \\
\hline Average P.I. & \\
\hline
\end{tabular}




\begin{tabular}{|l|c|}
\hline Distribution variance (P.I.) & 0 \\
\hline Standard deviation (P.I.) & 0 \\
\hline Average time taken & 65.20 \\
\hline Assessment highs & 75 \\
\hline Best percentage & 0.36 \\
\hline Best P.I. & $04: 30$ \\
\hline Best time & 0 \\
\hline Assessment lows & 0 \\
\hline Worst percentage & $\mathbf{0}$ \\
\hline Worst P.I. & \\
\hline Worst time & \\
\hline
\end{tabular}

\section{Source: www.cami.co.za}

The above table (Table 2 ) shows the performance in detail. The average percentage is $38,67 \%$ with a standard deviation of $0,81 \%$.

Figure 5 shows the frequency distribution of the overall marks of the students in all the five content areas.

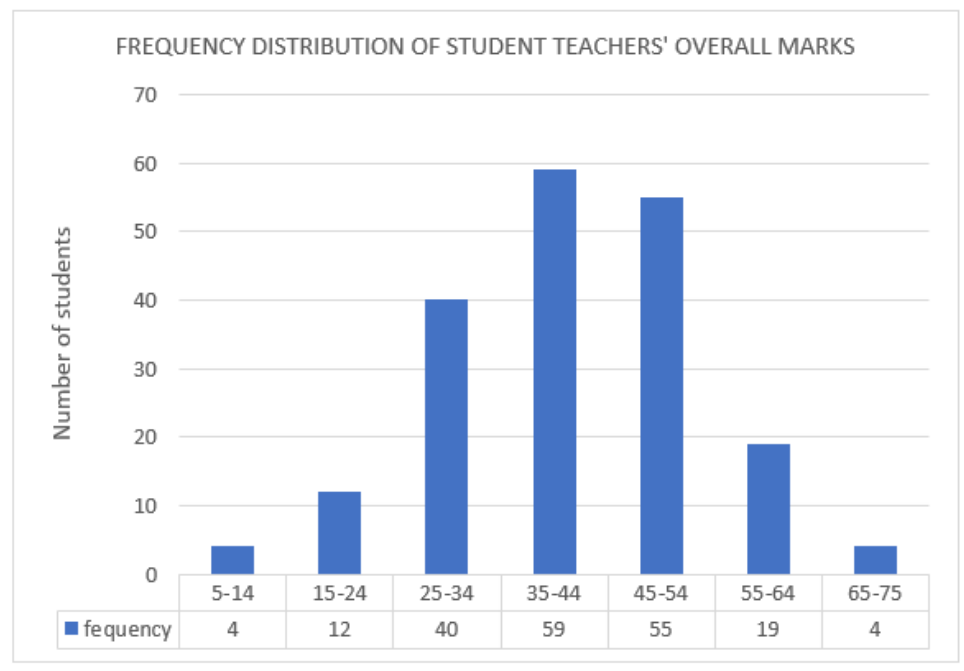

Figure 5: Frequency distribution of the overall student's marks

As shown in figure 5, most of the student teachers performed below average marks in all the main content areas. Only 23 students got ( $55 \%)$ and above while 55 student's marks fall between (45\%) and (54\%), and 115 student's marks are below (45\%). The highest number of the student teachers in the overall marks for Grade 7 assessment are within (35\%) and (44\%).

\section{Discussion}

The National Research Council (NRC, 1996) reports that subject content knowledge matters. Mathematicians and mathematics educators face a significant issue in deciding what subject matter to teach, to whom, and in what detail (NRC, 1996). This study agrees with Korthagen, Loughran, and Russell (2006) and Lai and Lo-Fu (2013) that pre-service teachers should be prepared to reconstruct their information and educational concepts into authentic classroom teaching. This study also 
accords with Hiebert, Morris, Berk, and Jansen (2007) and Kilic (2015), who argued that pre-service teachers should develop knowledge, abilities, and attitudes that will allow them to study their teaching and improve over time. The NRC (1996) reports that influenced by the Mathematical Association of America (MAA, 1983) recommendations, many universities provide special courses for prospective elementary teachers with titles like "Number Systems for Elementary Teachers" and "Geometry for Elementary Teachers." According to textbooks, teaching these topics at an elementary level while demonstrating instructional approaches fit for use in an elementary classroom is a common approach. At the advanced level, aspiring secondary teachers may study abstract algebra, linear algebra, geometry, and real analysis courses in addition to other mathematics majors, as well as courses specifically developed for prospective teachers.

Carpenter (1995), according to NRC (1996), contends that even when student teachers are taught additional subject in their undergraduate degrees, they do not always apply or retain that knowledge in their teaching. He claims that how student teachers learn the content is crucial, and that its relationship to future teaching practice is poorly understood; “...teachers need to understand how their content knowledge applies to their teaching... [so] that the content is learned in a context that provides some links with how that knowledge is used in teaching" (Carpenter, 1995, p. 23). This needs to be addressed in the teacher training.

South Africa also has the same situation as in USA as Latterell (2008) points out that even though pre-service teacher has knowledge of secondary mathematics, the evidence shows that preservice teachers do not have deep understanding of undergraduate mathematics as mathematics majors' students have. Latterell continues to mention that it is interesting that on most mathematics topics, the pre-service teachers felt very well qualified to teach them., but could not teach confidently more reform type topics, such as data collection and analysis, probability, statistics, and discrete mathematics (2008). This made Latterell (2008) to conclude that the pre-service teacher has a medium-level of commitment and a medium-level of ability to teach according to NCTM Standards. The present authors also concur with Latterell (2008) that our prospective teachers need to be equipped well to teach according to the CAPS requirements of the school mathematics.

It is not mathematics teacher training alone that goes through the same vicious cycle, as Deng (2001) points out that there is gap between what a physics teacher learns in the intellectual discipline of physics and what they teach in high school physics. However, in the scholarly debate on what science teachers should teach and what they should know, this gap has not been adequately addressed. According to Floden, McDiarmid, and Wiemers (1990), teacher educators may not even see teaching subject matter content as their responsibility, thinking that potential teachers obtain the content they need will be taught in their arts and science courses. If this situation is not addressed well in the teacher education courses, the student teachers' opportunities in acquiring the subject content knowledge will be limited.

Curricular knowledge is defined as knowledge of a variety of instructional programs and materials designed for teaching a particular subject or topic at a given grade level. It is evident that the student teachers are gaining it from the course modules on the methods of teaching. The current author also agrees with Zinn et al., who suggested that in teacher education, special attention should be devoted to the quality of student teachers' classroom and school-based learning, as well as its integration into the general teacher education curriculum (2014).

This research throws light into the neglected distinction that the concepts or principles that a mathematics teacher needs in helping high school students to understand a particular topic in senior secondary school mathematics differ in the discipline of mathematics in courses offered by the department of mathematics. Teachers of mathematics must comprehend mathematics in a different way than students in the mathematics department. Similar inference was noted by Deng (2001) that there should be two different kinds of concepts or principles in Physics, one for a physics teacher in teaching physics for high school students, and the other for a physicist in conducting scientific inquiry.

In 2014, the Initial Teacher Education Research Project (ITERP) investigated the nature and quality of Intermediate Phase initial teacher education programs offered by Higher Education 
Institutions (HEIs), as well as how effectively these programs met the educational demands of South Africa (Alex \& Robert, 2019). Students entering the B.Ed. program had very limited mathematical understanding, according to lecturers at the five universities, and student instructors were only managing mathematics subject at the Intermediate Phase level (4-6). (Bowie \& Reed, 2016). However, the landscape of ITE curricula offered to the student teachers is more under examination that the insufficient content and conceptual knowledge of a teacher contributes to poor attainment of learners especially in mathematics in South Africa (Rusznyak, 2015). Therefore, the solution to the poor attainment requires excellent ITE program in the HEIs.

Pournara, Hodgen, Adler \& Pillay (2015) cite the Study of Instructional Improvement by Hill et al. (2005), report that the mathematical-knowledge-for-teaching of Grade One and Grade Three teachers was a stronger predictor of learner attainment than were proxy measures, such as number of courses taken in Mathematics or Mathematics Methodology, or years of teaching experience, or average daily length of mathematics lessons. The authors of this paper also believe that MKfT matters.

\section{Conclusion}

According to the results of the baseline test, first-year ITE student teachers join the teacher education program with inadequate mathematical knowledge for teaching (MKfT). The ITE program's design provides a lot of hope that by the end of it, the student teachers will have learned enough mathematics to be able to teach their future students. The authors of this research suggest that during their preparation as prospective mathematics teachers, student teachers should be fully involved in learning the topic.

\section{References}

Alex, J.K. (2019). The Preparation of secondary school mathematics teachers in South Africa: Prospective teachers' student level disciplinary content knowledge: Eurasia Journal of Mathematics, Science \& Technology Education, 2019, 15(12). https://doi.org/10.29333/ejmste/105782

Alex, J.K. (2021). Teacher knowledge related to secondary school level geometry: Evidence from teacher development in South Africa: Virtual, ICME conference, July 2021

Alex, J.K., \& Roberts, N. (2019). The need for relevant initial teacher education for primary mathematics: Evidence from the Primary Teacher Education project in South Africa. Proceedings of the 27th Annual Conference of the Southern African Association of the Research in Mathematics, Science \& Technology Education, 15-17 January 2019. Edited by N Govender, R Mudaly, T Mthethwa \& A Singh- Pillay, pp 59-72. Long Paper. ISBN: 978-0-9922269-8-5

Ball, D. L., Thames, M. H., \& Phelps, G. (2008). Content knowledge for teaching: What makes it special. Journal of teacher education, 59(5), 389-407. [Online] Available: https://www.cpre.org/

Deacon, R. (2012). The Initial Teacher Education Research Project: The initial professional development of teachers: A literature review. Johannesburg: JET Education Services.

Department of Basic Education (2020). TIMSS 2019: Highlights of South African Grade 9 Results in Mathematics and Science. Accessed from www.tims-sa.org.za on 16 July 2021.

Jacinto, E. L., \& Jakobsen, A. (2020). Mathematical Knowledge for Teaching: How do Primary Pre-service Teachers in Malawi Understand it? African Journal of Research in Mathematics, Science and Technology Education, 24(1), 31-40. https://doi.org/10.108o/18117295.2020.1735673

Martínez, S., Guíñez, F., Zamora, R., Bustos, S., Rodríguez, B., (2020). On the instructional model of a blended learning program for developing mathematical knowledge for teaching. ZDM (2020) 52:877-891. https://doi.org/10.1007/s11858-020-01152-y

Nortvedt, G.A., Buchholtz, N (2018). Assessment in mathematics education: responding to issues regarding methodology, policy, and equity. ZDM Mathematics Education 50, 555-570 (2018). https://doi.org/10.1007/s11858-018-0963-z

Pournara, C., Hodgen, J., Adler, J. \& Pillay, V. (2015). Can improving teachers' knowledge of mathematics lead to gains in learners' attainment in Mathematics? South African Journal of Education, 35(3). https://doi.org/10.1570o/saje.v35nza1083 
Rocha, H. (2020). Using tasks to develop pre-service teachers' knowledge for teaching mathematics with digital technology. ZDM (2020) 52:1381-1396. https://doi.org/10.1007/s11858-020-01195-1

Rusznyak, L. (2015). Knowledge selection in initial teacher education programmes and its implications for curricular coherence. Journal of Education, (6o), 7-30. [Online] Available: https://www.journals.ukzn.ac.za

Sahidin, L., Budiarto, M. T., \& Fuad, Y. (2019, April). What Construct of Mathematical Knowledge for Teaching do Mathematics Teachers Need? (A Theoretical Framework and Conceptualization in Geometry). In 1st International Conference on Advanced Multidisciplinary Research (ICAMR 2018) (pp. 302-306). Atlantis Press 